\section{Overzichtslijst van het archief van SM Het Licht}

Piet Creve, departement archief AMSAB

Als nummer acht in de reeks AMSAB-Werkinstrumenten verscheen de beschrijving van het archief van SM Het Licht door archivaris Rik De Coninck. Het omvangrijke archief van deze Gentse socialistische drukkerij berust al geruime tijd bij het AMSAB, maar tot nu toe bestond er enkel een gedeeltelijke en dan nog rudimentaire beschrijving. Op te merken is dat in de eerste fase van deze verwerking assistentie is verleend door studenten Pers- en Communicatiewetenschappen van de Gentse universiteit in het kader van een seminarieoefening.

Rik De Coninck schetst in wat hij met een understatement een 'beknopte historische inleiding' noemt, het eerste volledige overzicht van de geschiedenis van deze coöperatie die het licht zag in 1908 en na een lange doodstrijd in 1986 uitsputterde. Vroegere deelstudies beperkten zich grotendeels tot de kranten die door SM Het Licht werden uitgegeven (Vooruit en De Morgen). Maar SM Het Licht was duidelijk meer dan een drukkerij van (partij) kranten. De samenwerkende vennootschap fungeerde als het propaganda-instrument par excellence door het drukken van affiches, brochures, congresdocumenten en dergelijke. SM Het Licht bekleedde een sleutelpositie in de politieke strategie van de Gentse socialisten. Eerdere studies waren gebaseerd op de kranten zelf en diverse feestnummers. Hier wordt voor het eerst van de archiefstukken gebruik gemaakt. De inleiding toont duidelijk aan dat dit archief een rijke bron kan zijn voor studies vanuit diverse invalshoeken: bedrijfseconomische, sociale, journalistieke...

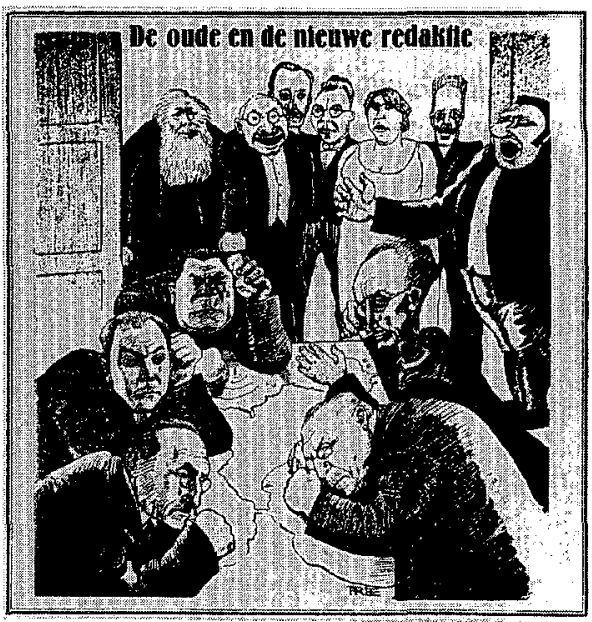

Tekening van Frits Van den Berghe

Met de overzichtslijst van het archief van Le Peuple, is dit de tweede beschrijving uit de socialistische perswereld die voorligt ${ }^{(1)}$. Het archief van Volksgazet is in volle verwerking. In het materiaal van SM Het Licht werden tal van stukken van andere archiefvormers aangetroffen, zoals van Gust Balthazar, August De Block en Het Nachtverblijf. Deze Gentse pluralistische filantropische instelling deed tot eind 1940 tijdens de winterperiode dienst als opvangcentrum voor rondtrekkende werklozen.

(1) K. ALDERWEIRELDT, Les archives du journal Le Peuple. In : Brood \& Rozen, (1997)3, p. 55-61.

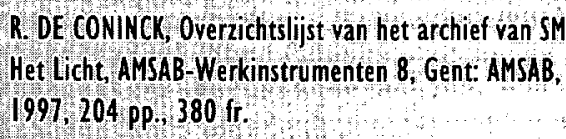
Het Licht, AMSAB-Werkinstrumenten 8, Gent: AMSAB, $1997.204 \mathrm{pp} .380 \mathrm{fr}$. 